\title{
Middle Eastern Proxy Wars Waged on the Background of Civil Wars
}

\section{Proxy války vedené na pozadí občanských válek na Blízkém východě}

\section{Mirela Atanasiu}

Abstract: The paper argues that proxy war is an increasingly often used tool in the Middle East, in the already conflicted territories where international involvement is not only enabled, but also attracted and encouraged by the international law for the purpose of region's securitization. Thus, the paper's aim is to increase awareness on the fact that the Middle Eastern countries passing through civil war periods and accepting external actors to deal with their crises do not only become fertile territories for proxy wars, but the intervening actors start pursuing their own interests beyond the host country's interest in resolving the conflict.

Abstrakt: Příspěvek predkládá tvrzení, že proxy válka je stále častěji používaným nástrojem na Blízkém východě na již konfliktních územích, na nichž je přítomnost zahraničních sil nejen umožněna, ale také vyžadována a podporována mezinárodním právem za účelem sekuritizace regionu. Cílem článku je tedy zvýšit povědomí o tom, že země Blízkého východu procházející občanskými válkami, které zapojují vnější aktéry do řešení krize, se stávají stále úrodnějším prostředím pro zástupné války, přičemž intervenční aktéři začínají prosazovat své vlastní zájmy nad rámec zájmu hostitelské země na vyřešení konfliktu.

Keywords: Proxy War; Hezbollah; Houthi; US; Iran.

Klíčová slova: proxy válka; Hizballáh; Húsíové; USA; Î́rán. 


\section{INTRODUCTION}

Civil wars are constantly present in the Middle Eastern security behaviour, bringing economic and statehood fragility to such states as Syria, Yemen or Iraq. Their weaknesses lead to insecurity in the region and thus these countries become candidates for foreign interventions.

Foreign interventions are multiplied in terms of used means (direct military support, particularly with airpower, but also land troops, finance and support for one party in the conflict, support offered to state actors - militia forces, policemen, national armed forces, etc. - and non-state actors - paramilitary troops, rebel forces, terrorist groups etc. - used as proxies in the conflict) and also in terms of the numbers of actors that lead to intricate and dynamically changing relations among the actors involved in the conflict.

A specific type of foreign intervention is a proxy war consisting in an actor's indirect involvement in the military conflicts going on in the politically fragmented and failed states by using proxies that may be state or non-state actors, with less or none of their own troops present. This instrument has become increasingly used in the Middle East as the failed states already caught in civil wars (Syria, Yemen, and Iraq) are a prolific ground for proxy conflicts.

Our identification of a proxy war starts from the hypothesis that this specific tool is used when two opponent entities do not want to directly fight or declare war because of financial costs, potential diplomatic loss or the risk of triggering an unwanted large-scale war.

A proxy war is seen by certain experts as „,an effort or series of efforts intended to advance one's security objectives at the expense of a rival using means beyond those associated with routine statecraft and short of means associated with direct military conflict." ${ }^{1}$ Also, a proxy war finds a fertile ground in the fragile states stemmed by conflicts among different parties fighting for territorial and political gains. Therefore, a state or non-state actor initiates a proxy war by getting involved in an already developing conflict.

Its involvement consists in supporting the war effort of one party in the conflict opposed to the other party supported by its direct rival in order to reach its own geopolitical goals and interests. Consequently, for the great power or regional powers, a proxy war offers an opportunity to gain hegemony around the world while appearing as a supporter of one party involved in the conflict rather than a conqueror, particularly when its intervention is based on the invitation of the government or political faction. Thus, increasingly, proxy wars are advantageous for the countries making profit from selling arms while they also offer the opportunity for covert state and non-state entities to try their new-developed weapons and train their paramilitary, mercenaries or private military companies' employees in real-time and real combat conditions without being punished by the international law.

1 DALTON, Melissa; SHAH, Hijab. 2020. Partners, Not Proxies Capacity Building in Hybrid Warfare. In: Center for Strategic and International Studies (CSIS) Briefs, May 2020, p. 1, https://csis-website-prod. s3.amazonaws.com/s3fs-public/publication/20528_Dalton_NotProxies_Brief_v7.pdf, [26.12.2020]. 
Concerning the Middle East, our research will be considering three ongoing civil wars - in Syria, Yemen, and Iraq - wherein a web of proxy wars is developing under the background of foreign involvement of state actors such as US, Russia, Iran, Turkey, Saudi Arabia, and Israel, who rely on their proxies in order to gain geopolitical advantages.

\section{METHODOLOGY}

The presented paper has two objectives: to identify and characterize civil wars in the Middle East and to show that there is an active and dynamic web of proxy wars overlapping in the civil war stricken territories, bringing insecurity to the region.

In terms of research methods, in the first part, the descriptive research using content analysis and empirical observation was used to present the pace and consequences of civil wars in the Middle East (Syria, Yemen, and Iraq). In the later part, a case study was built on the existence and features of proxy wars waged on the background of these civil wars. Therefore, the ongoing proxy wars waged in the aforementioned civil wars' territories were identified and analysed from the perspective of the involved state and non-state actors and the relations among them.

The limitations of the paper are mainly related to scientific resources in terms of the rapid pace of events in these civil and proxy wars, where the bibliographical sources are mostly mass-media open sources, as the expert literature is slowly updated over time, but also in terms of the language gap provided that parts of texts already translated by other authors from Arabic are used for the content analysis. Another limitation is related to the research itself as the paper does not attempt to present all dimensions of the described Middle Eastern proxy wars (i.e., each actor's motives of involvement in the presented proxy wars), but just to show that there is a trend in the evolution of foreign interveners' behaviour increasingly exploiting the civil war stricken territories to address their own disputes with other actors by using the proxy war instrument.

\section{THE EVOLUTION AND CURRENT STATUS OF MIDDLE EASTERN CIVIL WARS}

Since the Arab Spring, civil war has been constantly present in the Middle Eastern security behaviour. Poor economic conditions (poverty, inequalities, and low economic growth) and natural factors (natural resources, climate, and fragmentation of society) are considered the roots thereof, ${ }^{2}$ and as far as one might see, Syria, Yemen, and Iraq are the perfect candidates for it. All of them are economically failed states, they do not have

2 COUTTENIER, Mathieu; SOUBEYRAN, Raphael. 2013. An Overview of the Roots of Civil Wars: Natural Factors and Economic Conditions. In G-MonD Policy Papers, no. 2, Paris: School of Economics, January 2013, pp. 4-12. 
common governance on their entire territory, their societies are divided on political, ethnical and/or religious grounds, and they are at the brink of collapse, particularly in the COVID-19 pandemics, exposing their structural and functional gaps in terms of lack of medical facilities and sanitary infrastructure indiscriminately destroyed in the military confrontations.

\subsection{Syria - a decade of decayed conflict}

Ten years have passed since the Syrians launched peaceful civil protests against Bashar al-Assad demanding a change of political leadership. The situation quickly escalated into a more acute conflict, after the Syrian regime repressed the protesters, and quickly turned into a civil war with various factions engaged in a competition for political and territorial control.

The dynamic pace of events, amid the failure of the coalition government across Syrian territory, has created a political vacuum that has quickly drawn foreign powers into the Syrian conflict. Thus, today, in the power competition, on the one hand, Iraq, Iran, Russia, and the terrorist group Hezbollah from Lebanon fight alongside the Syrian regime of Bashar al-Assad and, on the other hand, the US-led coalition, Turkey, Qatar, Saudi Arabia, and Israel support the Syrian rebels. The Kurds in north-eastern Syria, the self-proclaimed Islamic State, and al-Qaeda-affiliated terrorist organizations have also entered the territorial competition. Thus, the internationalized civil war has turned into proxy conflicts, which the great powers (such as Russia, Iran, Turkey, and the US) are engaged in in a competition for regional supremacy and for the achievement of their own national interests to the detriment of a political answer to the needs of the Syrian people.

The direct result of the decade of the Syrian conflict is the humanitarian catastrophe. More than 500,000 people have died and about 13 million people have been displaced (more than half of the pre-war Syrian population), of whom 6.2 million are internally displaced persons and 5.6 million are refugees, mostly in Lebanon, Jordan, and Turkey. $^{3}$ Syria is also facing economic turmoil, widespread instability, and US sanctions since 1979, culminating in the Caesar Act, ${ }^{4}$ which extends the previous sanctions regime by including a paragraph providing for sanctions against Syrian government institutions and for those doing business with Damascus, which has only worsened the humanitarian situation, and despite calls by UN Special Rapporteur Alena Douhan to suspend them, ${ }^{\mathbf{5}}$ they are still in place.

3 United States Institute for Peace. USIP's Work in Syria, 26 August 2020, p. 1. https://www.usip.org/sites/ default/files/2020-09/the-current-situation-in-Syria.pdf, [12.12.2020].

4 Syria Justice and Accountability Centre. The Caesar Act: Impacts and Implementation, 20 February 2020, https://Syriaaccountability.org/updates/2020/02/20/the-caesar-act-impacts-and-implementation/, [26.06.2020].

5 UN News. UN rights expert urges United States to remove sanctions hindering rebuilding in Syria, 20 December 2020. https://news.un.org/en/story/2020/12/1081032, [16.02.2021]. 
At the same time, according to the World Bank, the protracted conflict in Syria has led to indirect economic and social consequences in the neighbouring countries, especially in Iraq, Jordan, and Lebanon. ${ }^{6}$ These regional consequences include "increased poverty rates, higher public debt, deteriorating labour markets, especially for young people and women, and more restricted access to public services such as healthcare and electricity. ${ }^{\text {"7 }}$ Thus, the Syrian conflict has projected insecurity to the whole region.

The withdrawal of US troops from the Syrian battlefield at President Trump's request in 2019 has not only facilitated the continuation of the Turkish military action against the Syrian Kurds, with their displacement in other territories, but has also increased uncertainty about the role of other foreign parties involved in the conflict as well as the future of internal actors. In fact, experts say that „external military intervention - including the supply of weapons and military equipment, training, airstrikes and even troops - in support of the parties vying for political power in Syria threatens to prolong the conflict." 8 Moreover, the civil war is complicated by competing external state actors providing military support for opponent sides (US-Russia, Turkey-Russia, Israel-Iran, Iran-Saudi Arabia) and operating closer and closer to each other, which raises concerns about the possibility of an unintentional escalation of the conflict.

At the same time, it is worrying that ongoing violence, ${ }^{9}$ proxy conflicts between foreign actors in Syria and the emergence of COVID-19 may facilitate the resurgence of terrorist groups. In fact, ISIL attacks escalated in 2020 in terms of geographical extent, lethality and complexity, a fact highlighted by doubling the number of attacks and pro-government fighters killed and tripling the number of organized attacks compared to 2019. ${ }^{10}$ Regarding the proxy wars on Syrian territory, experts believe that the most dangerous confrontation in Syria is the Israeli-Iranian one, as it has the greatest potential to attract the great powers, the US and Russia, ${ }^{11}$ into direct war, which could lead to the transformation of the conflict into a large-scale armed clash.

In March 2020, on the one hand, Turkish forces with the Syrian rebels, and, on the other hand, Russian forces with Bashar al-Assad's governmental forces, agreed to sign a ceasefire agreement for the Idlib province, settling a security corridor and deploying joint Russian-Turkish patrols to secure the area. The agreement lasted for several

6 World Bank Group. The Fallout of War: The Regional Consequences of the Conflict in Syria, 17 June 2020. https://www.worldbank.org/en/region/mena/publication/ fallout-of-war-in-Syria, [12.12.2020].

7 The World Bank. The Ripple Effects of the Syrian Conflict in the Mashreq Region, 17 June 2020. https:// www.worldbank.org/en/news/press-release/2020/ 06/17/fallout-of-war-in-Syria, [12.12.2020].

8 Council on Foreign Relations. Civil War in Syria. In Global Conflict Tracker, 2 March 2021. https://www.cfr. org/global-conflict-tracker/conflict/civil-war-Syria, [03.03.2021].

9 In 2020, 9,321 violent events took place in Syria, of which: 2,253 military clashes, 57 protests, 5,451 explosions, 1,560 violent acts against civilians. To be seen: ACCLED database. Syria. 2021. https:// acleddata.com/dashboard/\#/dashboard, [14.02.2021].

10 WATERS, Gregory. ISIS in Syria: 2020 in Review, New Lines Institute for Strategy and Policy, 10 February 2021, https://newlinesinstitute.org/isis/isis-in-Syria-2020-in-review/, [15.02.2021].

11 HINNEBUSCH, Raymond. Proxy Wars and Spheres of Influence in Post-Isis Syria, IEMed. Mediterranean Yearbook, 2020. p. 82. https://www.iemed.org/observatori/arees-danalisi/arxius-adjunts/anuari/ med.2020/Proxy_Wars_Syria_Post-Isis_Raymond_Hinnebusch_IEMed_YearBook2020.pdf, [20.02.2021]. 
months, during which time no large-scale air raids took place and some of the displaced returned to their native areas still under the control of armed anti-government groups. But, in September 2020, amid continuing Turkish-Kurdish fighting on the Syrian border, civil protests calling on the Turks to withdraw from the border with Syria, and attacks on the Idlib region (currently the largest stronghold of rebel forces), Russia's air raids resumed.

In the beginning of 2021, Assad's regime controlled almost the whole of the territory but did not succeed to restore full sovereignty on Syrian soil. Still, he decided to reduce readiness of the armed forces „ordering a rollback of army mobilization to regular level, meaning the level maintained before the start of the conflict." $\mathbf{1 2}$ There can be at least three motives: a hoax of war, the tightening of finances used to support own armed forces, or to convey a message to Syrians and to the world before the mid-2021 elections that the regime is in control of the country. But, as the peaceful protest taking place in Idlib and other rebel-held parts of Syria marking 10 years of conflict in March 2021 went undisturbed by the governmental forces, while the Syrian economy is getting lower, one might consider Assad decision to scale down Syrian armed forces is not a tactic of war against adversaries but a result of political-economic motives. Also, on 11 March 2021, Turkey, Russia, and Qatar launched a trilateral consultation process in order to push for a political resolution in Syria. ${ }^{13}$ Still, with the new escalating violence of ISIL, proxies' military actions and dynamically shifting alliances among the parties involved in the conflict, the civil war is not over and Syria seems far from stabilization.

\subsection{Actuality and perspectives of Yemeni civil war}

Yemen is facing the worst food security crisis in the world, with 20.1 million people - almost two-thirds of its population - in need of food assistance. ${ }^{14}$ In 2020, Yemen was the most fragile state in terms of cohesion, economic, political and social indicators measured by the Fund for Peace. ${ }^{15}$ In fact, it has recorded the most acute humanitarian crisis of the moment, all the more so as COVID-19 has added more suffering to Yemeni civilians.

In Yemen, the main struggles for political and territorial supremacy are between: forces of the UN-recognized government, led by President Mansur Hadi (supported by the coalition led by Saudi Arabia and composed of the UAE and other predominantly

12 Al-KHATEB, Khaled. Why Assad is scaling down military readiness across Syria, Al-Monitor, 2021. https:// www.al-monitor.com/originals/2021/01/Syria-assad-reduce-military-readiness-iran-funding-elections. html, [21.03.2021].

13 CHMAYTELLI, Maher; GUMRUKCU, Tuvan; BALMFORT, Tom. Turkey, Russia, Qatar to push for political resolution in Syria, Reuters, 11 March 2021. https://www.reuters.com/article/us-Syria-crisis-qatar-aid/ turkey-russia-qatar-to-push-for-political-resolution-in-Syria-idUSKBN2B31QH, [23.03.2021].

14 Human Rights Watch. Yemen. 2021. Events of 2020. In World Report 2021. https://www.hrw.org/worldreport/2021/country-chapters/yemen, [20.03.2021].

15 Decade Trends 2010-2020. Fragile State Index 2021. https://fragilestatesindex.org/data/de, [22.03.2021]. 
Sunni Arab states); the Supreme Political Council (SPC), represented mainly by Houthi rebel forces (supported by Iran); the Southern Movement, represented in particular by the Southern Transitional Council (STC) - a southern separatist movement apparently supported by the UAE; terrorist organizations such as Al-Qaeda in the Arabian Peninsula and the Islamic State.

The pandemics was an opportunity for Al Qaeda in the Arabian Peninsula (AQAP) and the local ISIL affiliate, who took advantage of the created chaos and captured new territory in the south, carrying out other deadly attacks, especially in Aden.

In northern Yemen, fighting intensified when Houthi forces confiscated new areas held by the Yemeni government, following military offensives in more than 40 separate battles in 11 governorates, compared to 31 battles in 7 governorates in 2019. ${ }^{16}$ Thus, by the end of 2020, most of the territory was controlled by the Houthi rebel forces (about $70 \%$ of the country's population).

In April 2020, the leader of the anti-Houthi coalition, Saudi Arabia, announced a unilateral ceasefire due to the COVID-19 pandemic that was rejected by the Houthi forces amid calls for the lifting of air and sea blockades in Sana'a and Hudaydah, ${ }^{17}$ with hostilities continuing without taking into consideration such a scenario. Later, after the US withdrew their military support to the Saudi-led forces, in March 2021, another ceasefire offer was proposed by Saudi Arabia, but it was also declined by the Houthi. It is clear that Saudi Arabia wants to get out of the conflict and the sole reason to remain here is the fear that if it unilaterally withdraws from the conflict, Iran will gain a strong foothold on the Saudi-Yemeni border.

In South, in January 2020, there was a sudden escalation in both ground and air combat theatres. The situation continued at this pace until April 2020 when the Southern Transitional Council (STC) assumed self-government in Aden, aiming to govern the port city and the southern provinces. ${ }^{18}$ This political declaration triggered a new violent episode between STC and the government of President Hadi. However, in December 2020, following negotiations between the two, an accord was reached on the implementation of the Riyadh Agreement mediated by Saudi Arabia aimed to resolve the conflict in southern Yemen. In this context, the STC agreed to be part of the Hadi government in exchange for the permission to move the government back to Aden. Thus, in February 2021, a new government was formed.

This situation offers a prospect of easing part of the conflict in Yemen by the implementation of the Riyadh Agreement, and the new government formation is an opportunity for southern secessionists to join forces with the Hadi government against the Houthi forces, which would be a turning point for the balance of forces in the conflict and maybe a leverage to bring the Houthi to the discussion table. Also, Saudi

16 ACLED database. 2021. The myth of stability: infighting and repression in Houthi-controlled territories. https://acleddata.com/2021/02/09/the-myth-of-stability-infighting-and-repression-in-houthi-controlledterritories/, [11.02.2021].

17 Idem.

18 BBC News. Yemen crisis: Why is there a war?, 19 June 2020, https://www.bbc.com/news/world-middleeast-29319423, [11.02.2021]. 
Arabia's disengagement intentions must be taken into consideration when prospecting the trajectory of the Yemeni civil war.

\subsection{The intricate web of the Iraqi civil war}

In Iraq, two main conflicts are taking place. The first one is waged between the Iraqi government forces (Iraqi Armed Forces, the Popular Mobilization Forces dominated by Iran-aligned militias ${ }^{19}$ and Peshmerga - the military representing the Autonomous Kurdistan region of Iraq) and Iraqi anti-government protesters calling for the end of the existing political system. The second conflict is conducted by the US-led coalition comprising regional states (Turkey, Saudi Arabia, and UAE) helping the Iraqi government in fighting against ISIL. Also, since 2018, NATO is present, having established an advisory, training and capacity-building mission in Iraq (NMI) to help strengthen the Iraqi security forces to fight against ISIL.

The waves of anti-government protests of the population that started in October 2019 triggered by „endemic corruption, high unemployment, dire public services and foreign interference ${ }^{\prime 20}$ continued and there were clashes with security forces that resulted in casualties on both sides. ${ }^{21}$ In May 2020, a new government led by Mustafa al-Kadhimi was formed, but despite proposed reforms in the electoral system, the legal sector or the public health sector, by the end of the year, this government failed to make much progress due to pressure from divergent interests of tribes and its inability to bring them to the negotiation table. Its sole achievement was to set the term of the Iraqi elections for 10 October 2021. Owing to the non-existent advance in the promised reform, in the beginning of 2021, anti-government demonstrations were organized in defiance of COVID-19 lockdown, which resulted in deaths among the protesters after the government forces opened fire.

Still, there are also other military clashes taking place, for example, the Turkish military and Peshmerga against the Kurdish rebels, in northern Iraq (Kurdistan Working Party, or PKK), who claim more rights for the Kurds in Turkey. Also, there is a multiple number of militias in Iraq with dispersed loyalties and different focus: pro-Iran faction of the Kata'ib Hezbollah, part of the Popular Mobilization Forces, trained by Lebanese Hezbollah, acts against US-led forces, but also against Saudi Arabia;22 Iraq's Atabat units,

19 Examples of such units are: Asaib Ahl al-Haq, Kataib Hezbollah, Kataib Sayyid al-Shuhada, and the Badr Brigade. ALAALDIN, Ranj. Containing Shiite Militias: The Battle for Stability in Iraq. In: Policy Briefing, Brooking Doha Center, December 2017, p. 1.

20 BBC News. The Iraq protests explained in 100 and 500 words. 2 December 2019. https://www.bbc.com/news/world-middle-east-50595212, [13.03.2021].

21 Human Rights Watch. Iraq. Events of 2020, 4 November 2020, https://www.hrw.org/world-report/2021/ country-chapters/iraq\#, [14.01.2021].

22 KNIGHTS, Michael; MALIK, Hamdi; AL-TAMIMI, Aymenn Jawad. The Future of Iraq's Popular Mobilization Forces. In: Policy Watch 3321, The Washington Institute for Near East Policy, 28 May 2020. https://www. washingtoninstitute.org/policy-analysis/future-iraqs-popular-mobilization-forces [24.03.2021]. 
paramilitary groups, cooperate with Iraq's Ministry of Defence in opposing the Iranian dominance, ${ }^{23}$ the Badr Brigade militia is the Iranian-trained wing of the Supreme Council for the Islamic Revolution in Iraq (SCIRI), the most powerful Shiite party in Iraq ${ }^{24}$ fighting against ISIL.

The Iranian air-strike retaliations on Iraq territory following the US airstrike in Iraq that resulted in the killing of Qassem Soleimani, the commander of Quds Force of the Iranian Islamic Revolutionary Guard Corps (IRCG) and of Abu Mahdi al-Muhandis, deputy commander of the Iran-backed Popular Mobilization Forces (PMF) and founder of the Kata'ib Hezbollah brigades, destabilized US-Iraq relations, with the Iraqi parliament ${ }^{25} \mathrm{ca}-$ lling for the „removal of US troops from the country ${ }^{\text {“26 }}$ and the Iraqi protesters attacking the US embassy in Baghdad.

The Iraqi request was pertinent in the context in which the Islamic Caliphate was declared physically non-existent, although fears remained that the US withdrawal would accelerate Iran's growing influence and could lead to the revitalization of Islamist terrorism; these fears later materialized in both respects. Thus, at the repeated insistence of the Iraqi government, the US government established a timetable to reduce, by early 2021 , the US military presence in Iraq to 2,500 people. ${ }^{27}$ Still, in the coming months, a series of Iranian rocket attacks were perpetrated against US troops in Iraq and military acts of US retaliation against Iraqi paramilitary forces linked to Iran ${ }^{28}$ were initiated. These actions provoked even more negative reactions from Iraqi officials, who saw the transformation of Iraq's territory into one of the US-Iran proxy wars, carried out in the context of the new Gulf crisis.

Other security issues, which have persisted in Iraq despite the pandemic, are linked to "disputing its internal borders by Kurdish regional authorities and the continuing risk of escalating regional tensions in north-eastern Syria with the potential to affect Iraq's western border. ${ }^{\prime 29}$ Also, Turkish airstrikes targeting the Kurdish Kurdistan Free Life Party of Kurdistan (PJAK) and members of the Kurdistan Workers' Party (PKK) based in

23 Idem.

24 BEEHNER, Lionel. Iraq's Militia Groups, Council on Foreign Relations, 3 March 2008. https://www.cfr.org/backgrounder/iraqs-militia-groups, [19.03.2021].

25 There are a number of Tehran-affiliated groups in the Iraqi parliament that hold political power. A similar trend exists in the Iraqi armed forces where armed groups such as Kataib Hezbollah became part of the People's Mobilization Forces (PMF), formed to fight ISIL in 2014. See: FALK, Thomas O. What the US troop withdrawal means for Iraq. Al Jazeera. 22 November 2020. https://www.aljazeera.com/news/2020/11/22/ what-the-us-troop-withdrawal-means-for-iraq, [22.01.2021].

26 The Associated Press. Iraqi parliament votes to kick US troops out following killing of Soleimani, 5 January 2020. https://www.militarytimes.com/news/your-military/2020/01/05/iraqis-vote-to-kick-us-troops-outfollowing-killing-of-soleimani/, [26.01.2021].

27 Global Conflict Tracker. Political instability in Iraq, 3 March 2021, https://www.cfr.org/global-conflicttracker/conflict/political-instability-iraq, [03.03.2021].

28 FANTAPPIE, Maria; HELLER, Sam. In Iraq, restraint is America's best option. In: War on Rocks, 30 March 2020, https://warontherocks.com/2020/03/in-iraq-restraint-is-americas-best-option/, [28.12.2020].

29 United Nations Development Program in Iraq. Impact of the oil crisis and COVID-19 on Iraq's fragility, August 2020, p. 19. 
northern Iraq have created insecurity in Iraq. ${ }^{30}$ In fact, the Iraqi authorities fear that the Kurdish autonomous region could become the scene of a proxy war between Turkey and the United Arab Emirates (UAE), the latter being suspected of financially supporting the PKK in the Kurdish secessionist campaign against Turkey.

There were reports that the Islamic State has taken advantage of the pandemic, filling the void left by the reduction of US military forces in the context of the decision to withdraw them, but also of Iraqis amid the COVID-19 pandemic (military service personnel decreased by $50 \%),{ }^{31}$ escalating attacks from local intimidation to more complex tactics, such as attacks and ambushes with improvised explosive devices. Thus, in February 2021, at the Iraqi government request, NATO announced it would expand its mission to train Iraqi forces in their fight against ISIL, partially reversing the US-led troop withdrawals.

\section{CASE STUDY: ON-GOING PROXY WARS AND ACTORS IN MIDDLE EASTERN CIVIL WAR STRICKEN COUNTRIES}

For a better understanding of relations between power projecting actors, supported parties in the conflict, and used proxies in the Middle East, this chapter will investigate part of proxy wars in Syria, Iraq, and Libya, which were more active in the beginning of 2021.

\subsection{The proxy war between the US and Russia}

The proxy war between the US and Russia has been going on since the Cold War, when the US and the USSR manifested themselves through rivalry proxies without risking a direct military confrontation that could lead to nuclear war. This is a lasting conflict due to the ongoing competition between the two powers for global supremacy, which is currently taking place in a context where the US is the greatest superpower in the world and projects its geopolitical influence also in the Middle East, and for the Russian Federation, after the dissolution of the USSR, the Middle East is a field to promote its foreign policy thinking ${ }^{32}$ by supporting and promoting multi-polarity in global politics in order to counteract the US status as a unipolar core of power and to increase its chances of

30 Human Rights Watch. Iraq. Event of 2020, doc. cit.

31 Peace News. Iraq: How COVID-19 is impacting peace and conflict, 19 October 2020. https://www. peacenews.com/single-post/2020/10/19/iraq-how-covid-19-is-impacting-peace-and-conflict, [12.03.2021].

32 SERVICE, Robert. Russia and American Power in the Middle East. In The Caravan, Issue 2027, Hoover Institution, 1 September 2020. 
projecting its own power in the international arena along with other powers in the world (China, India, Japan, etc.).

In Syria, the US backs-up the Syrian Democratic Forces - „a Kurdish-led multi-ethnic force comprising of Kurds, Arabs and other ethnic groups created in 2015 to support the US-led coalition in the war against ISIL,"33 the Syrian opposition groups, namely the National Coalition for Syrian Revolution and Opposition Forces (SNC) founded in Qatar, but also other associated anti-government groups. Russia supports the pro-Assad Syrian forces ground personnel „primarily of special forces, which focused on training, advising, and assistant partner forces and conducting special reconnaissance missions "34 and supplies air support to the Syrian Arab Army (SAA), which in turn is divided in two factions supporting Russia and Iran. ${ }^{35}$ Thus, in time, SAA could balance in one direction or the other. Also, it is assumed that Russia is using mercenaries (Wagner Group) unofficially pushing the Russian interests abroad.

In Yemen, at first, the US supported the Saudi-led coalition attacking Houthi rebel forces, while Russia played the card of strategic non-alignment to distinguish itself from the US involvement policy and therefore to increase its soft power in the Middle East. Meanwhile, the US stopped supporting Saudi Arabia militarily and Russia started to get actively involved in the conflict via its proxy - the Russian Wagner Group paramilitary forces (supporting the LNA).

Over the past few years, amid suspicions of Russian interference in the US 2016 elections, NATO naval exercises in the Black Sea, the strengthening of Russia's position in the Middle East, and armed confrontations in Syria (where they support opposing parties in the conflict), American-Russian relations tensed and fell down to a minimum similar to the Cold War era. Moreover, altercations in Europe, off the coast of Alaska and the Middle East have increased tensions between the two rival powers, with a constant risk of escalation.

Biden-Putin relation got strained again in March 2021 in the context the US intelligence report stating that Russia used Trump's allies to influence the 2020 election to denigrate the actually elected president. ${ }^{36}$ Therefore, also in the immediate future, President Biden's government is expected to focus on pursuing US domestic issues, namely managing the COVID-19 pandemic, ensuring economic recovery, and mitigating social and political divisions in the country, in the detriment of the foreign policy, while

33 European Asylum Support Office. Syria Actors Country of Origin Information Report, December 2019, https://coi.easo.europa.eu/administration/easo/PLib/2019_12_EASO_COI_Report_Syria_Actors.pdf, [15.03.2021].

34 BORSHCHEVSKAYA, A. Shifting Landscape, Russia's military role in the Middle East. Washington Institute for Near East Policy, September 2019, p. 5

35 KASAPOGLU, Can. Could Russia Lose the Syrian Arab Army to Iran or General Maher al-Assad? In: Terrorism Monitor Volume, 18 Issue, The Jamestown Foundation Global Research and Analysis, June 2020, p. 13. https://jamestown.org/program/could-russia-lose-the-Syrian-arab-army-to-iran-or-general-maher-alassad/, [16.03.2021].

36 COHEN, Zachary; COHEN, Marshall; POLANTZ, Katelyn, US intelligence report says Russia used Trump allies to influence 2020 election with goal of 'denigrating' Biden, CNN News, 16 March 2021. https:// edition.cnn.com/2021/03/16/politics/us-election-intel-report/index.html, [21.03.2021]. 
president Putin also cannot neglect the same focus in the internal affairs. The strategic security game between the two great powers will not stop and, obviously, neither will the use of proxy wars to achieve their own goals. These developments will be highlighted, in particular, in the way these actors will further relate to the Syrian crisis, but also to the Iranian nuclear issue.

\subsection{The US-Iranian proxy war}

There has been an opposition in the Middle East for some time between the US-led anti-Iran alliance involving Israel, Saudi Arabia, the UAE, and partly Egypt against the anti-American alliance consisting of Iran and its local allies - the militias from Syria, Yemen and Iraq, and Hezbollah. ${ }^{37}$ Thus, amid political tensions over the past two years, such as the US withdrawal from the nuclear deal with Iran (JCPOA) and the re-imposition of sanctions on Iran in 2018, as well as the appointment, in April 2019, of the Islamic Revolutionary Guard Corps (IRGC) - a branch of the Iranian army - as a foreign terrorist organization, in 2019 a Persian Gulf crisis was triggered. Moreover, the two leading opponents risked military confrontations when Iran shot down an American drone over the Strait of Hormuz and the US carried out airstrikes against Iran-backed Shiite militias in Iraq in response to alleged attacks perpetrated by them. Consequently, against this already critical background, tensions escalated between the two warring parties in May 2019, when four US oil tankers were hit by explosions in the Gulf of Oman, although Iran denied allegations that its forces planted mines on the ships. ${ }^{38}$ Subsequently, the US strengthened its military presence in the region to deter any similar campaigns planned by Iran and its non-state allies, aimed at attacking US forces and interests in the Persian Gulf and Iraq.

In Yemen, the US has supported the Saudi-led coalition in fighting against the Houthis and helped those forces push back on Iran. Also, SDF Kurdish People's Protection Units are suspected of being used as a proxy against Iran, by the US-led Global Coalition to Defeat ISIL forces. ${ }^{39}$ Along with the military support, the US also designated Houthi rebels as a terror group in the Trump era, but President Joe Biden decided to shift this American policy by reversing the decision. In here, Iran supports a Zaidi Shi'a military group, the Houthis, opponent to the internationally recognized governmental forces.

37 HILTERMANN, Joost, Tackling Intersecting Conflicts in the MENA Region, International Crisis Group, 15 January 2020. https://www.crisisgroup.org/middle-east-north-africa/tackling-intersecting-conflictsmena-region, [23.03.2021].

38 BBC News. Iran and the crisis in the Gulf explained, 19 August 2019, https://www.bbc.com/news/ worldmiddle-east-49069083, [22.03.2021].

39 For example, BBC news „US-led coalition has denied carrying out air strikes on Iran-backed Iraqi Shia militiamen in eastern Syria after a deadly attack on its troops in Iraq." BBC News. Iraq base attack: Coalition denies strike on Iran-backed fighters in Syria, 12 March 2020. https://www.bbc.com/news/world-middleeast-51850880, [12.03.2021]. 
In Iraq, Iranian-linked militias are embedded in the Iraqi security force, the Popular Mobilization Force (PMF); also, Iran's Quds Force and its Lebanese proxy, Hezbollah, are directly involved in training, arming, and funding Special Groups, and the US uses as its proxies the Iraqi security forces, particularly the Counter-Terrorism Forces, Kurdish militia and some Sunni tribal leaders. ${ }^{40}$

In early 2020, after the death of Iranian General Soleimani, commander of the Quds Forces (IRGC's body), an Iranian air strike in Baghdad followed and the Gulf crisis intensified. Moreover, in the context of this crisis, a series of proxy wars of the Middle East (Iran-Saudi Arabia, Iran-Israel, Qatar-Saudi Arabia), but especially that of the US-Iran, have intensified. Thus, even in the context in which both states are among the most medically, economically and socially affected by the pandemic, the hard power instruments of the two (military and economic) continue to manifest themselves in offensive actions (for example, in May 2020, a dangerous encounter between the Iranian and American naval forces took place in the Persian Gulf, following which President Trump declared that the American armed forces would retaliate if such events were repeated). ${ }^{\mathbf{4 1}}$

The fact that the new US President Joe Biden expressed his readiness to re-sign the nuclear agreement with Iran is a hint that the new US administration looks for diplomacy toward Iran. However, a return to the nuclear deal without further changes and adjustments could lead Israel and the Gulf States to acting together against the agreement, against the US and Iran, or it could lead to the disintegration of the Abraham Accords. Whatever scenario follows between the two, the Middle East will not be pacified; an optimal option would be an adjusted JCPOA by consulting with the Arab states and Israel in order to reach a compromise solution for all.

\subsection{The proxy war between Iran and Saudi Arabia}

The proxy war between Iran and Saudi Arabia, also called the „Cold War in the Middle East, “42 is in fact a persistent struggle for a regional hegemony in the Middle East manifested against the double condition: both are regional powers and dispute power supremacy over the oil-fields in the region, while they are also rivals on the background of the schism between the Shi'a and Sunni denominations of Islam. Thus, in the context of these antinomies, the two got involved in the military conflicts of some states in the region, financially or materially supporting opposing parties:

40 OLLIVANT Douglas A.; GASTON, Erica. The problem with the narrative of 'proxy war' in Iraq. War on Rocks, 31 May 2019. https://warontherocks.com/2019/05/the-problem-with-the-narrative-of-proxy-war-in-iraq/, [12.02.2021].

41 VAEZ, Ali. The US and Iran are still perilously close to conflict, The Guardian, 2 May 2020.https:// www.theguardian.com/commentisfree/2020/may/02/us-iran-military-hotline-covid-19-pandemic [19.01.2021].

42 GAUSE III, F. Gregory. Beyond Sectarianism: the New Middle East Cold War, Brookings Doha Center Analysis Paper, Brookings Doha Paper, Number 11, July 2014. 
- In the Syrian war, Iran used its own national forces (for example, Quds and Basij militia forces of the Islamic Revolutionary Guard Corps) and also sponsored proxies (Lebanese Hezbollah militia, Harakat Hezbollah al-Nujaba ${ }^{43}$ Iraqi paramilitary force) to support Bashar al-Assad's government; Saudi Arabia supported the rebel forces but facing Russian involvement in the conflict and further reluctance of the US, Saudi Arabia gradually shifted its tactics by trying to reach out to Bashar al-Assad.

- In the Yemeni conflict, Iran supported the Houthi rebels by providing weapons, while Saudi Arabia supported the recognized government of Yemen by using the assets of the Saudi-led coalition created against Iran in 2015 (UAE, Yemen, Kuwait actively participated in the coalition with "logistical and intelligence support from the US, UK and France“), helped on the ground by autochthonous „pro-Saudi factions, such as the tribal militias of the powerful al-Ahmar family. ${ }^{44}$ Still, there have been reports lately that „the UAE has largely diverged from the Saudi-led coalition's anti-Houthi war in northern Yemen ... [and prefers to support] the Southern Transitional Council (STC), a governing entity that seeks an autonomous South Yemen along pre-1990 borders and whose leadership shares the UAE's worldview of apolitical Islam. "45 Also, one can see that Saudi Arabia has lost the US support and tries to exit from the conflict as soon as possible but with less geopolitical damage. Thus, it seems Saudi Arabia has lost the case to Iran in both of the proxy fronts.

\subsection{The proxy war between Iran and Israel}

Another incandescent proxy war in the Middle East is between Iran and Israel, particularly on its Syrian component, where Israel opposes Iran's involvement in supporting Bashar al-Assad alongside Russia. In the conflict against Iran, Israel is supported by the US, Saudi Arabia, Azerbaijan, but also by the Mujahedeen People of Iran, the People's Resistance Movement of Iran (PRMI) and the Iranian Kurdish Party for the Free Life of Kurdistan. Iran fights back with „Lebanese Hezbollah, the Afghan Fatemiyoun Brigade, the Pakistani Zeinabiyoun Brigade, as well as various Iraqi Shi'a militias that are members of the Iraqi Popular Mobilization Forces, and fighters from Yemen. “46

This conflict has lasted for more than 40 years, after a period of oscillating relations between friendly and conflict. Over time, Iran's actions in support of Hezbollah in Lebanon, as a way to indirectly confront Israel, as well as Israel's option to remain allied

43 The Movement of the Noble of Hezbollah.

44 Carnegie Middle East Center, Into the Maelstrom: The Saudi-Led Misadventure in Yemen, 26 March 2015. https://carnegie-mec.org/diwan/59500?lang=en [22.03.2021].

45 KRAUSE, Peter; PARKER, Tyler B. Yemen's proxy wars explained. In: Political Violence at a Glance, MIT Center for International Studies, 2020. https://cis.mit.edu/publications/analysis-opinion/2020/yemensproxy-wars-explained [12.02.2021]

46 European Asylum Support Office. The Government of Syria and associated armed groups. In: Country Guidance. Syria, September 2020. https://easo.europa.eu/country-guidance-Syria/11-government-Syriaand-associated-armed-groups, [12.02.2021]. 
with the West (especially with the US) and to attack Iranian targets in the territories of other states also contributed to the increase of tensions. Their proxy war has a long history, still, Israel's air raids against Iranian backed-militias in Syria and Iranian targeted attacks against Israeli military installations in the Golan Heights multiplied in the recent years.

In April 2020, Israeli Defence Minister Naftali Bennett made the following statement: „We have moved from blocking Iran's entrenchment in Syria to forcing it out of there, and we will not stop. ... We will not allow more strategic threats to grow across borders without taking action. "47 It is a clear shift in Israel's strategic objectives, reflecting a shift in the power dynamics of the Syrian civil war. In this context, the series of attacks in which Iranian missiles from Syria were aimed at Israel and air attacks were carried out by Israel on Iranian targets in Syria has also multiplied. In fact, Israel stated that in 2020 it hit more than 50 Syrian government, Iranian or Hezbollah targets in approximately 1,400 operational flights in Syria. ${ }^{48}$ Iran, amid a major pandemic ignored in the first instance, is under unprecedented domestic social and economic pressure as a result of the US sanctions. In the immediate future, this situation will likely lead the Iranian state to the need to focus more internally and to put less pressure on its external efforts to build the position as a regional power.

\subsection{Russia-Turkey proxy war in Middle East}

Initially, this rivalry was expressed by proxies on the Syrian front, with Turkey supporting part of the rebel forces, while the Russians backed the Assad government. Thus, on the one hand, Turkey backs-up the Syrian National Army (SNA) armed group based in northern Aleppo under the supervision of the so-called Syrian Interim Government's Ministry of Defence, including „Sultan Murad Brigade: Arab-Turkmen group from Aleppo; The Moutassem Brigade: formerly US-backed rebels; Ahrar al-Sharqiya: Islamist faction from eastern Syria; al-Jabha al-Shamiya (the Levant Front): Islamists from Aleppo and Azaz". ${ }^{49}$ The National Liberation Front (NLF) formed in 2018 by rebel armed groups in the Idlib area (including Ahrar al-Sham, ${ }^{50}$ the Noureddine al-Zengi Brigades, Failaq al-Sham, ${ }^{51}$ Jaish al-Ahrar, ${ }^{52}$ and groups that fought under the Free Syrian Army banner,

47 Al-KHALIDI, Suleiman. Syria says Israeli helicopters strike targets in southern Syria, Reuters, 1 May 2020. https://www.reuters.com/article/uk-Syria-security-israel-attacks/Syria-says-israeli-helicopters-striketargets-in-southern-Syria-idUKKBN22C3UP?edition-redirect=uk [08.02.2021].

48 Asharq Al-Awsat. Israel says it Hit 50 Syria Targets in 2020, 31 December 2020. https://english.aawsat. com/home/article/2713596/israel-says-it-hit-50-Syria-targets-2020 [18.01.2021].

49 European Asylum Support Office. Anti-government armed groups. In Syria, September 2020. https://easo. europa.eu/country-guidance-Syria/11-government-Syria-and-associated-armed-groups [19.01.2021].

50 Army of Conquest.

51 The Sham Legion.

52 Army of the Free. 
such as the Victory Army and the $2^{\text {nd }}$ Coastal Division) has also received support from Turkey. ${ }^{53}$ On the opposite side, Russian airplanes bombed Ahrar al-Sham, ${ }^{\mathbf{5 4}}$ funded by Turkey and Saudi Arabia to bolster Syrian opposition forces.

The opening of a new Turkish front in addition to the existing one in Syria, in early 2020 , with the deployment of about 4,000 troops to Libya ${ }^{55}$ to support the UN-recognized government in Tripoli, while Russia was the supporter of Khalifa Haftar, escalated the tensions between Russia and Turkey and created a credible hypothesis about the triggering of an open conflict between the two. Moreover, this possibility seemed even closer in March 2020 when Russian-backed Syrian forces attacked a Turkish military outpost in the Idlib province, resulting in the death of more than 30 Turkish soldiers. ${ }^{56}$ The attack sparked a Turkish military reaction; Turkey responded by attacking Syrian forces and Russian-made anti-aircraft weapons. Subsequently, Russian warships in the Black Sea fleet crossed the Bosporus to increase the presence of the Russian navy in the eastern Mediterranean.

In October 2020, under an UN-backed ceasefire signed by the new Libyan unity government, foreign troops and mercenaries (also Russian and Turkish) were to be pulled out of Libya since the end of 2020, but in March 2021 they were still present despite the UN's demands. ${ }^{57}$ Also, the US demand Russian, Turkish and UAE troops out of Libya. Thus, one might say the Russian-Turkish proxy war has lost a territory of action.

\subsection{The future of proxy wars in the Middle East}

Through good US offices in second term of 2020, the UAE, Bahrain, Sudan and Morocco announced the resumption of bilateral relations with Israel. These agreements mark the tendency to normalize relations between Israel and the Arab states, but also to improve efforts towards regional pacification, by isolating Iran.

In parallel with the normalization of relations with Israel, for a similar political and geopolitical reason, Saudi Arabia, Bahrain, but also the United Arab Emirates and Egypt, have decided to normalize their relations with Qatar and end the embargo against it.

53 LUND, Aron. 2018. Syrian war: Understanding Idlib's rebel factions. In The New Humanitarian, 3 September 2018. https://www.thenewhumanitarian.org/analysis/2018/09/03/Syrian-war-understanding-idlib-srebel-factions [25.01.2021].

54 Stanford University. Ahrar al-Sham. In: Mapping Militant Organizations, 5 August 2017. https://web.stanford.edu/group/mappingmilitants/cgi-bin/groups/view/523 [18.02.2021].

55 BBC News. Libya conflict: Turkey sends troops to shore up UN-backed government, 6 January 2020. https://www.bbc.com/news/world-africa-51003034 [04.02.2021].

56 RONDEAUX, Candace. NATO Is in Denial about the Risk of War between Turkey and Russia. In: World Politics Review, 6 March 2020, https://www.worldpoliticsreview.com/ insights/28583/for-nato-turkeyrussia-war-is-a-nightmare-scenario [23.03.2021].

57 Al Jazeera. Libya demands mercenary pullout; Syrian militia on its way. 25 March 2021. https:// www.aljazeera.com/news/2021/3/25/libya-demands-mercenary-pullout-as-eu-top-diplomats-visit, [25.03.2021]. 
The re-normalization of these two sets of relations could lead, in the medium term, to the formalization of the third, between Qatar and Israel (which is already cooperating on issues related to the situation in Gaza), and of, course, the strengthening of US-led coalition against Iran. Thus, in this context, one may say that as Israel and the Arabs see a deeper common stake in peace and prosperity, it will be more difficult for Tehran to pursue an asymmetric crisis-inducing strategy in the Middle East. For the United States, the Abraham Accords contribute to the idea of forming a local coalition that maintains the regional balance of power and limits Iran, which will help it focus on its strategic rival, China.

Actually, over the past decade, China has significantly increased its footprint in the economy and politics of the Middle East, becoming the largest trading partner and foreign investor for many countries in the region. But as tensions develop between the two superpowers, the US and China, the tendency of Gulf States to build closer ties with China and security is visible, although known to be historically entrenched in the US sphere of influence. Consequently, China's military involvement will obviously trigger an US-China proxy war developed in the Middle East civil wars territories.

\section{CONCLUSIONS}

Proxy wars are waged by a series of state actors aiming to pursue their political goals and military supremacy over a region with the help of other forces than their own. Thus, in the Middle East, there is a complex and dynamic web of proxy relationships fuelled by divergent and changing interests of actors (for example: in Yemen, UAE as a part of the Saudi-led coalition against Iran has recently supported the separatists in the south, while the coalition stands supporting Hadi's internationally-recognized government; in Syria, US forces left the room for Turks regardless of their Kurdish allies; Russia intends to become militarily involved in Iraq while it declared a non-intervention posture in the past, etc.). This is owed to the fact the interveners have their own political agenda and enmities in the region, and they are tempted to forget their main goal in the host country, the region's pacification remaining a second tier of their actions.

Middle East hosts a series of proxy wars that overlap in terms of territories, state actors and used proxies. For example, Syria hosts a number of military rivalries on its territory, expressed by their proxies' actions (US-Russia, US-Iran, Russia-Turkey, Iran-Saudi Arabia, Iran-Israel), Yemen is the house of proxy tensions between Iran-Saudi Arabia, Iran-United Arab Emirates, Qatar-UAE as well as Iran-Israel, and Iraq is already the place of the clashes between the US and Iran and risks to become a proxy territory for the Turkey-UAE conflict. Some proxy wars take place in more than one place, namely the US-Iran conflict going on in all three identified civil wars territories. Thus, the Quds Force of Iranian IRCG operates in all of the three countries - in Syria it supported the formation of pro-government militias, in Iraq it helped with the establishment of the PMF, and in Yemen it supported the Houthi government in Sana'a against the Saudi pressure. The same applies to the Hezbollah militias, another Iran's proxy operating in Syria, but also in Iraq. 
The research has shown that sometimes the decisions or actions of proxy war promoters have led to the brink of high intensity conflict between great powers. Thus, the military intervention of foreign actors exacerbated by proxy war not only does not bring security, but can create more insecurity in the region.

Among the worst consequences of proxy war developments, the most obvious is the triggering of the Persian Gulf crisis generated by the US-Iran rivalry and complicated by the Iran-Israel antinomy and regional fragmentation on the grounds of different religious beliefs and ethnicity, as well as historical grievances. Actually, the proxy war focus in the Middle East was marked by the relocation of the centre of gravity of the regional conflict over the US-Iran dispute and the partial military disengagement of the US from the region, Russia winning from both actions, which, on the one hand, brought Iran closer, and, on the other hand, it gained ground and increased influence in Syria as a result of the vacuum created by the departure of American forces.

Over the past decade, China started to build closer ties with some of the Gulf States, some of them US allies and, in the long run, this trend can take the shape of a US-China proxy war in the Middle East.

Author: $\quad$ Mirela Atanasiu, PhD. Born in 1978. She is a senior researcher and has an interdisciplinary education (post-PhD studies in crisis management, PhD in Military Sciences and Information, MA in public communication in the security field, bachelorship in international law). She is active within the Centre for Defence and Security Strategic Studies, "Carol I" National Defence University, Bucharest, Romania and is mainly involved in scientific research related to Middle Eastern and North African security, focusing on the study of terrorism, extremism, crises and conflicts, and foreign actors involved in the region. She authored or co-authored 18 area studies, more than 90 conference papers, and 40 scientific articles in the field of security and defence.

How to cite:ATANASIU Mirela. Middle Eastern Proxy Wars Waged on the Background of Civil Wars. 2021, 30 (3), 027-044. ISSN 1210-3292 (print), 2336-2995 (online). Available at: www.vojenskerozhledy.cz 